\title{
USE OF ARTTHERAPY TECHNIQUES IN PEDAGOGICAL ACCOMPANIMENT OF CHILDREN WITH SPECIAL EDUCATIONAL NEEDS
}

\author{
Petro KuZENKO, OleXANDRA KuZENKO, LiUdMYla MATSUK
}

\begin{abstract}
The article emphasizes the fact that the problem of providing effective pedagogical support for personal development of children with mental and physical disabilities occupies an important place in the educationa theory and practice of modern Ukraine. Among scientists there are different approaches to determining its content, purpose and objectives. Most researchers consider pedagogical support of children with special educational needs (SEN) assystematic actions and measuresaime datensuring positive results in the educational process. The main tasks of pedagogical support of children with psychophysical developmental disorders are to ensure their social adaptation and over come difficulties in communicating with peers; prevention of problems of personal development and upbringing of the child; providing assistance in solving current educational problems and socialization; implementation of psychological and pedagogical counseling for parents. The authorsempha size that art therapy is rightly considered to be an effective means of pedagogical influenceon children with SEN in an inclusive educational space. Art therapy as a method of diagnosis, change and resource development of an individual, group or team through the use of different art sand their own creative activities has a wide field of application in various areas of teaching. To achieve a positive result in the pedagogical support of children with SEN the following arttherapy means are used: drawing therapy, fairy-tale therapy, sand therapy, music therapy, photo therapy, color therapy, which can be integrated, completing each other. It is scientifically proven that theuse of different types of arts contributes to the development of a child's emotional and communicative sphere, the establishment of interpersonal communication, taking into account emotional state of peers. During art therapy classes peculiarities of interpersonal communication are revealed, obstacles in its establishment are found and over come, and as a result the development of social-communicatives kills of children with SEN.
\end{abstract}

Keywords: pedagogical support, art therapy, children with special educational needs, inclusive education, social and communicative skills.

\section{INTRODUCTION}

The modern Ukrainian educational space is on the way of reforming and finding options to humanize the process of education and upbringing of children with SEN. In the context of this application of therapeutic possibilities of art in pedagogical support of children with special educational needs acquires special attention and urgency, because it is by means of art therapy a set of diagnostic, correctional, educational tasks in an inclusive educational space can be effectively solved. 
The effectiveness of art therapy in the recovery and harmonization of personality development has been proven in the theory and practice of ensuring the socio-psychological adaptation of children with mental and physical disabilities. Many years of experience in the use of art therapy working with children with disabilities in Western Europe and the United States have proven its corrective and developmental significance. In modern Ukraine during the last decade, the use of art therapy working with children with special educational needs has intensified not only as a diagnostic technology, but also for developing personal resources.

\section{RESULTS AND DisCUSSION}

The main directions in the theory and practice of art therapy were: 1) game technologies in modern art (L. Tikhonovych, 2005); 2) medical and rehabilitation possibilities of systemic art therapy (O. Ionov, 2005; O. Kopytin, 2011; L. Bilozorova, 2011); 3) pedagogical aspects of art therapy and the development of creative potential of the individual by art therapy means (L. Lebedeva, 2001; G. Grishina, 2004); 4) formation of social experience and correction of maladaptation in society (O. Medvedeva, 2007; S. Kurakina, 2007, T. Kiselyova, 2009), etc. [12].

Tested areas of using the therapeutic potential of art in the pedagogical support of children with special educational needs are drawing therapy, music therapy, puppet therapy and fairy-tale therapy. The research and development of art-therapy practice in independent Ukraine involves the scientific research of I. Dmytrieva, U. Dutchak, I. Kuzava, L. Kunenko, Z. Leniv, I. Lysenkova, O. Nakonechna, O. Fil, I. Chernukhaand etc. These works reveal the psycho-correctional and psychotherapeutic possibilities of different types of art in harmonizing the development of different categories of children, including those with functional limitations. The results of numerous studies on the use of art therapy techniques in correctional and developmental work with different categories of children with disabilities have proven that they can be used not only by psychotherapists during special classes, but also in integtation by correctional educators, practical psychologists, speech therapists, music educators.

In connection with the introduction of inclusive education, the focus of theorists and practitioners in the field of education has become the scientific development of the latest models of psychological and pedagogical support of children with SEN in a group of peers with typical development. Having identified this problem as one of the priority areas of special pedagogy, Ukrainian scientists are actively working to specify the content and objectives of psychological and pedagogical support for preschoolers with special educational needs as a complex, dynamic process involving all members of the support team to develop the child's potential and meet his/her needs.

Pedagogical support of children with special educational needs is guided by the principles of humanistic, personality-oriented approach. Its content and objectives are directly related to the need to ensure the right of all children, without exception, to quality education and conditions of personal development. With this in mind, the priority of psychological and pedagogical support in inclusive education is to create conditions for education, training, socialization of children with SEN, meeting their needs and realization of their capabilities [9].

In modern theory and practice of education, psychological and pedagogical support is considered as a multifaceted problem. This concept was first introduced into scientific circulation in the 90s of the twentieth century. The authors G. Bardier, I. Romazan and T. Cherednykova in the book "Psychological support of the natural development of young children" (1993) first used this term. Problems of organization of psychological and pedagogical support are also reflected in the works by A. Derkach and M. Batiyanova. In these research works psychological and pedagogical support is considered as a system of professional activity of the teacher. It is able to ensure the creation of special conditions for the full development and successful learning of the child. M. Batiyanova emphasizes that a psychologist and a teacher in this process are not only observers of a child, but also active persons who create optimal conditions for his/her development, going side by side [10, 2]. 
In the research of the foreign scientist E. Kozakova the substantiation of the concept of support as a new educational technology is carried out. According to her, support is a method that can provide favorable conditions for expressing the ability to make optimal decisions in various educational or life situations. At the same time, according to E.Kozakova, support is a guarantee for the child and parents to receive the necessary assistance and relevant support for the entire period of its implementation by representatives of the relevant services for children, who have problems with psychophysical development and do not attend preschool establishments. Researchers note that the theoretical basis of support is that the child's development in each case depends on his/her capabilities, parents' efforts and the support of the environment.

The results of the analysis of foreign research show that the basic principles of the model of pedagogical support for the development of children with special educational needs during preschool are as follows: independence, empathy, self-realization, personal development, adaptation to reality, the ability to self-control in various life circumstances. In the studies of I. Hardy, K. Horney, K. Jung, G. Marie, G. Murray and others the vital need of each person for support is argued. This involves compassionate care, concern and protection [1].

According to domestic researchers, the main task of psychological and pedagogical support is to ensure personal development. In accordance with its directions and stages of personal development, specific tasks are determined. Thus, the tasks of psychological and pedagogical support are as follows: creating conditions for the socialization of the child in an inclusive educational environment; assistance in the development of personal qualities in accordance with the age period; assistance in establishing communication with peers; formation of a value attitude to one's "me", confidence in one's own strength, in one's potential capabilities; support in overcoming problems in educational activities [3].

A specialist in psychological and pedagogical support should not only be able to apply diagnostic, corrective techniques and provide counseling, but also show analytical skills in assessing problem situations. Moreover, for educators who provide psychological and pedagogical support professional skills to program and plan work aimed at solving pressing problems by co-organizing all subjects of the educational process - children, peers, parents, teachers, administration are very important [10].

Summarizing different views of scientists on the content and objectives of psychological and pedagogical support, it can be argued that its purpose in an inclusive educational environment is to create favorable conditions for all children, including those with SEN.

The main directions of its implementation in the practice of educational institutions are as follows:

- providing conditions for self-realization of the individual through the use of modern educational technologies;

- coordination of the content of the curriculum to meet the cognitive needs and capabilities of children with SEN;

- ouylining work with parents to identify and develop the abilities of children with SEN;

- coordination of the work of specialists to provide each pupil / student with individual recommendations and assistance [10].

Psychological and pedagogical support of children with special needs in an inclusive educational space provides solutions to individual problems of each pupil. First of all, specialists help children with SEN to acquire skills necessary for their adaptation in the team of peers and educational activities. Among the leading tasks of psychological and pedagogical support of children with special needs, researchers identify the diagnosis of strong and problematic aspects of personality development. Besides, important is the activity of the support team in order to identify and localize the problem during the integration of the child in the inclusive group of children, systematic monitoring of this process to study their individual characteristics, capabilities, interests and needs [4].

The efficiency of psychological and pedagogical support of pupils with special educational needs depends on the degree of consideration of their psychological and pedagogical features in the organization of the educational process. The category «children with special educational needs» includes children whose educational opportunities and needs do not meet the generally accepted age norm. This group includes children with disorders of psychophysical development, gifted children and 
children from socially vulnerable groups. A very large group among children with special educational needs are children with special needs (disorders) of psychophysical development. They are characterized by deviations from the age norm of physical or mental development, which are caused by congenital or acquired disorders. This category of children includes children whose health prevents the mastery of educational programs without creating special learning conditions due to temporary or permanent deviations in physical and (or) mental development [8].

Depending on the type of disorder in special pedagogy, different groups of children with peculiarities of psychophysical development are differentiated: with hearing impairments (deaf, with acquired deafness, with hearing loss); with visual impairments (blind, with acquired blindness, visually impaired); with intellectual disabilities (mentally retarded, with mental retardation); with speech disorders; with disorders of the musculoskeletal system; with a complex structure of disorders (mentally retarded blind or deaf; deaf -blind, etc.); emotional and volitional disorders and children with autism.

Various types of art therapy are an effective means of psychological and pedagogical support for children with SEN. It is through art that the positive emotional attitude of children with SEN to communicate with peers and adults is gained. The use of art therapy techniques provides favorable conditions for communication. To achieve a positive result in the pedagogical support of children with SEN the following art therapy techniques might be used: drawing therapy, fairy-tale therapy, sand therapy, music therapy, photo therapy, color therapy. They can be integrated, completing each other [13].

The use of art therapy techniques has a positive effect on the development of sensory-motor coordination. This, in turn, coordinates the interhemispheric interaction, involving both hemispheres of the brain in the process of creating. Due to this, the functioning of concrete-image and abstract-logical thinking takes place. Drawing, promoting the development of vision, motor coordination, speech, thinking, coordinates their interaction [6].

Art therapy as a means of socio-cultural rehabilitation of children with special needs has significant potential in relieving emotional stress. Drawing allows children to feel and understand their state of mind and feelings, visualize internal conflicts, develop empathy and emotional decentration [5].

In the pedagogical support of children with SEN it is necessary to take into account that art therapy has different drawing techniques, in particular: chaotic drawing (doodles, spots), diagnostic (complete the picture), plot (for example, technique "my family"), thematic (who I want to be in the future), situational (my mood at the moment) and many others. According to each of them, experts recommend use of different methods of practical implementation and specific materials. At the same time, the only rule of organizing the use of art therapy techniques is creation of comfortable conditions for artistic and creative activities of children [11].

It is important to take into account the therapeutic value of color in the organization of pedagogical support for children with SEN. Color affects a person, his/her mood, health, so its value should not be underestimated. Each color of the optical spectrum can individually change the psycho-emotional and physiological state of the child. Teachers must keep in mind that red, orange and yellow have a stimulating effect, while green, blue and purple - a sedative effect.

Playing with sand is of interest to all categories of children with SEN, even with an autistic spectrum of disorders. Sand therapy (Sand-Play) can relieve nervous tension, improve mood, evoke various associations. With the help of tactile contact with sand, the child not only relieves stress, but also learns about oneself and his/her inner world. Practically all types of drawing on a sand table: using a finger, a nail, an edge of a palm, palms, with the help of two hands, fists, toys are applied in pedagogical support of children with SEN.

The appropriacy of using music in working with children with mental and physical disabilities is justified, above all, by the fact that music has a positive effect on both emotional and physical condition. It is scientifically proven that a certain musical instrument has therapeutic value for a certain organ of the human body. For example, a guitar is for the heart, a saxophone- for the kidneys, a trumpet-for the pancreas, a drum- the spine, a harp- the lungs, and so on. Music therapy is also an 
important factor in the development of communication skills of children with SEN, as music creates a favorable environment, a positive socio-psychological climate in the group of preschoolers. In practice, it is proved that the development of communicative skills is optimized by their music and game activities [2].

Use of music therapy in the pedagogical support of children with SEN allows to create an artistic, favorable communicative environment for interpersonal communication. When listening to music, as well as involving children with SEN in music and play activities, a special communicative state of mind is created. This allows them to better understand them selves and other people. Favorite intonation, timbre and tempo of the sound, which the child hears, are a kind of standards for the regulation of his/her own voice in speech, as well as identifyimg the intonation of other people's speech. [2].

As a means of corrective influence in the pedagogical support of children with SEN, fairy tale therapy is widely used. In practice, its effectiveness is in the socialization and integration of the personality of a child with functional disorders in the environment of peers, the establishment of their interaction with the outside world through the development of communication skills. Fairy-tale therapy creates conditions for the transfer in an accessible form for children's understanding of complex ideas about life, the rules of social communication and finding common solutions [14].

Fairy tale therapy provides positive results in correctional and developmental work with children, which are characterized by various types of emotional and behavioral disorders, difficulties in perception, feelings of shame, guilt and more. Also, the use of fairy tale therapy promotes the development of coherent speech in children with complex speech disorders, acting as an effective means of overcoming speech defects, logophobia. This, in turn, normalizes their emotional state, as it allows children to feel confident in their own abilities [7].

\section{CONCLUSIONS}

Thus, in foreign and domestic science an active research of the effectiveness of art therapy in working with children with mental and physical disabilities takes place. An important development was the use of art therapy in correctional and developmental work with this category of children in an inclusive educational space. Art therapy, having psychotherapeutic, diagnostic, corrective and educational capabilities, is an important means of harmonizing the personal development of children with SEN. Personal development of pupils with functional disorders is realized in the process of artistic and creative activity, during which they are in emotionally comfortable conditions. The means of art therapy create a "success situation" necessary for children with special educational needs, as a result of which they form a sense of emotional comfort, satisfaction with their activities, faith in their own abilities, dignity and self-esteem. Due to the use of art therapy methods in the pedagogical activities of children with special educational needs, their emotional support is provided during social adaptation and overcoming difficulties in communicating with peers; prevention of problems of personal development and upbringing of the child; providing assistance in solving current educational problems; implementation of psychological and pedagogical counseling for parents.

\section{REFERENCES}

[1] Vaskivska S.V. Socio-psychological support of clients: Technology of consultative dialogue: textbook. W. Glavnyk, Kyiv, 2006. (in Ukrainian)

[2] Vatamanyuk H.P. Music and game activity as a means of for ming communicative skills of senior preschoolers. Pedagogical education: theory and practice, 18 (2015), 401-407. (in Ukrainian)

[3] Zymjanskyj A. Stages and tasks of psychological and pedagogical support of personal development of the future teacher. Youth and the market, 6 (2016), 40-43. (in Ukrainian) 
[4] Kompanec N.M., Lucenko I.V., Koval L.V. Organizational and methodological support of a child with special educational needs at school: teaching manuals. "Atopol", Kyiv, 2018. (in Ukrainian)

[5] Klymenjuk N.V. Theuse of integrated arttherapy in the process of socio-cultural rehabilitation of children with special needs. Available at: http://lib.chdu.edu.ua/pdf/naukpraci/pedagogika/2008/97-84-9.pdf. (in Ukrainian)

[6] Voznesenska O.L., Sknar O.M. (Eds.) The concept of introducing art therapy in children's hospitals. Milenium, Kyiv, 2007. (in Ukrainian)

[7] Conceptual principles of arttherapy in correctional pedagogy. Available at: http://static.klasnaocinka.com.ua/uploads/editor/4453/382333/sitepage_81/files/vistup_na_novickoi_n_b .pdf. (in Ukrainian)

[8] Matsuk O., Kuzenko O. Psychological and pedagogical research of current problems of implementation of preschool inclusive educationin Ukraine. Youthandmarket, 2 (181) (2020), 99-106. (in Ukrainian)

[9] Psychological and pedagogical support and supportinterms of modernization of educational space. Available at: http://osvita.ua/school/method/upbring/1334/. (in Ukrainian)

[10] Psychological and pedagogical support of a gifted childas a realization of personality-oriented approach. In: Dubasenyuk O.A. (Ed.) Professional-pedagogical education: personality-oriented approach: monograph. Publ.by ZDU im. IvanaFranka, Zhytomyr, 2012. (in Ukrainian)

[11] Sadova I.I. Use of arttherapy technologies of health correction in work with primary school students. Pedagogical education: theory and practice, 18 (2015), 309-313. (in Ukrainian)

[12] Khilia A. Art Therapy as an object of scientific research in the works of foreign and native scientists. Pedagogical sciences: theory, history, innovative technologies, 5 (59) (2016), 394-405. (in Ukrainian)

[13] Hrebtova N. The use of innovative correctional and compensatory technologies in speech therapy work with children. Available at: http://marganets-dnz5.edukit.dp.ua. (in Ukrainian)

[14] Shyk L.A. Fairy tale therapy in work with preschoolers."Osnova”, 2012. (in Ukrainian)

Address: Petro Kuzenko, Liudmyla Matsuk, Vasyl Stefanyk Precarpathian National University, 57

Shevchenko St., Ivano-Frankivsk 76018, Ukraine;

Olexandra Kuzenko, Ivano-Frankivsk National Medical University, 2 Halytska St., Ivano-

Frankivsk 76000, Ukraine.

E-mail: kuzenko_14@i.ua; plo4447@ukr.net; oleksandrakuz@ukr.net.

Received: 20.01.2021; revised: 18.03.2021.

Кузенко Петро, Кузенко Олександра, Мацук Пюдмила. Використання арт-терапевтичних технік в педагогічному супроводі дітей із особливими освітніми потребами. Журнал Прикарпатського університету імені Василя Стефаника, 8 (1) (2021), 141-147.

Стаття присвячена проблемі забезпечення ефективного педагогічного супроводу особистісного розвитку дітей із порушеннями психофізичного розвитку, яка займає важливе місце в освітній теорії та практиці сучасної України. Автори наголошують, що серед основних завдань педагогічного супроводу дітей із психофізичними порушеннями розвитку є: забезпечення їх соціальної адаптації та подолання труднощів у спілкуванні з однолітками; запобігання виникненню проблем особистісного розвитку і виховання дитини; надання допомоги у вирішенні актуальних освітніх завдань і соціалізації; здійснення психолого-педагогічного консультування батьків. У якості дієвого засобу дієвим педагогічного впливу на дітей із ООП в інклюзивному освітньому просторі розглянуто арт-терапію, яка виконує діагностичні та корекційно-розвивальні функції в забезпеченні розвитку особистості, групи чи колективу завдяки використанню різних видів мистецтва та власної творчої діяльності. Дия досягнення позитивного результату в педагогічному супроводу дітей із ООП застосовуються такі арт-терапевтичні напрями як: ізотерапія, казкотерапія, пісочна терапія, музична 
терапія, фототерапія, кольоротерапія. Застосування педагогами, психологами, музичними керівниками різних видів мистецтв в умовах інкдюзивної освіти сприяе розвитку в дітей із ООП емоційної та комунікативної сфери, налагодженню міжособової комунікації з однолітками. Під час арт-терапевтичних занять виявляються та долаються перешкоди в налагодженні комунікації, а таким чином і розвиток соціально-комунікативних умінь дітей із ООП.

Ключові слова: педагогічний супровід, арт-теарпія, діти з особливими освітніми потребами, інкдюзивна освіта, соціально-комунікативні уміння. 